\title{
Series shifts and mergers in the obstruent phonology of Tahltan (Northern Athabaskan)*
}

\author{
John Alderete, Simon Fraser University \\ Amber Blenkiron, Simon Fraser University \\ Edōsdi (Judy Thompson), University of Victoria
}

A survey was conducted to investigate the development of the Proto-Athabaskan obstruent series, ${ }^{*} t s / t \grave{s} / t \breve{s}^{r} / k$, into present day Tahltan. Results from seven native speakers and quantitative analysis of a larger corpus establish $t \theta / t s / t s / t s$ as the standard obstruent system, alongside three alternate systems that relate to independently motivated historical changes. These findings support the longheld view that differences in the obstruent reflexes do not reflect deep phonological differences among Northern Athabaskan languages, but instead represent areal influences and patterns of individual variation in a highly dynamic language network.

\section{Introduction}

A recurring theme in Athabaskan linguistics is that the task of classifying Northern Athabaskan languages into historically meaningful subgroups is fraught with a myriad of contact phenomena. Instead of traditional tree-based subgroupings, contemporary research tends to analyze similarities among languages as the result of waves of structural features across groups that have had extended contact (Krauss 1964; Krauss 1973; Krauss \& Golla 1981; Rice 2004). Attempts to posit taxonomic subgroupings, as in Hoijer (1963), lead to major divisions among languages that are obviously closely related. The language complex of Tagish/Tahltan/Kaska is a case in point. Krauss and Golla (1981) argue that these languages are nearly identical in lexicon and grammar, but they have three rather different obstruent systems, defying analyses that these differences reflect deep historical divergences.

We accept the fact of prolonged contact in these languages, but would like to point out that, in some cases, the factual basis motivating the wave model was based originally on limited information. More recent research has shown that the obstruent system of the standard variety of Tahltan is parallel to Kaska, with both languages shifting Proto-Athabaskan ${ }^{*} t s / t \check{s} / t \check{s}^{r} / k$ to $t \theta / t s / t s / t \grave{s}$ (Hardwick 1984; Nater 1989). This fact weakens the language contact argument somewhat, because the overlap in grammar and lexicon correlates with the same shifts.

The main goal of this report is to investigate the series shifts and mergers in Tahltan and relate our findings to Athabaskan historical phonology. In particular, we examine the speech of seven native speakers with a questionnaire designed to elicit the development of four obstruent series. In addition to documenting the standard variety, our results reveal two new obstruent systems in active use. It turns out that all of these systems, including a fourth system assumed in Krauss and

\footnotetext{
${ }^{*}$ We are grateful to Tanya Bob, Tad McIlwraith, Sharon Hargus, Pat Moore, Bill Poser, Keren Rice, Patricia Shaw, and Siri Tuttle for useful comments and questions, and also Michael Krauss for expert advice throughout the project, including detailed assistance designing our questionnaire. A special thanks is also due to all the Elder consultants who so graciously took the time to explain their language to us. This research was supported in part by a postdoctoral fellowship from the National Science Foundation (SBE-9904360) and a partnership grant from the Social Science and Humanities Research Council of Canada (895-20121029).
} 
Golla (1981), are either identical to those of neighboring languages or can be derived from them through independently motivated processes. Thus, while initially a cause for concern, Tahltan actually seems to strengthen Krauss and Golla's argument for the wave model. It is not simply the case that three closely-related languages have very different obstruent systems. The same language has four.

The rest of this article is organized as follows. In section 2 we situate the language and describe some of the dynamics of Tahltan speaking communities relevant to our analysis. Section 3 provides the historical perspective necessary for understanding structural similarities and differences that exist among Northern Athabaskan languages. In section 4, we give a quantitative analysis of the distribution of obstruents in a corpus of 455 stems, documenting the structure of Tahltan with more rigor and some statistical facts relevant to the development of obstruents. Section 5 presents the results of an investigation of eight native speakers and analyzes the four attested systems within Northern Athabaskan historical phonology. Section 6 gives some concluding remarks.

\section{Language background}

Tahltan is a Northern Athabaskan language of Northwestern British Columbia, Canada. It is spoken by fewer than 50 speakers, mostly concentrated in the communities of Dease Lake, Iskut, and Telegraph Creek. Using traditional sociolinguistic criteria, Krauss \& Golla (1981) assume that Kaska and Tagish are the most closely related languages. Historical ties with other Athabaskan groups have also been documented for Sekani, Tsetaut, Carrier, Slavey, and Witsuwit'en, as well as with coastal Tlingit, Taku Tlingit, Gitksan/Nisga'a, Haida, Cree, and Coast Tsimshian (Thomas McIlwraith, personal communication, and our consultant interviews). The identification of distinct Tahltan dialects and varieties is not a simple matter because we began research on the language while it was in a moribund state, and the salient linguistic features observed in inter-speaker variation do not correlate straightforwardly with known communities or immigration patterns. However, the results of our survey in section 5 describe one of the most important facets of this variation.

Some facts about Tahltan ethnography and the lives of the native speaker consultants provide additional context. All of the consultants were bi-lingual in English and Tahltan, and many of them are also fluent in, or had significant contact with, additional languages. The consultants were also raised in their traditional territory prior to the opening up of northwestern British Columbia with the construction of the Cassiar-Stewart Highway. As a result, the elder consultants led very traditional lives, engaging in subsistence hunting and fishing and regularly traversing long distances, often on foot. The consultants also have rather diverse historical backgrounds, with one being born in Shesley, a historically Kaska-speaking area, two others with ancestral ties to Bear Lake Sekani people, and still others with historical ties to Tlingit and Cree people. As has been remarked in other ethnographic accounts of Tahltan society (McIlwraith 2012; Sheppard 1983), these communities are dynamic places where there is constant contact with other Athabaskan speaking and non-Athabaskan speaking language groups.

We would like to note that members of these communities sometimes refer to their language with anglicized Tahltan, but also sometimes as Tättān [ta:łta:n], and the latter name is written as such, using the Tahltan orthography, in web resources such as the First Peoples' Cultural Council language map. We use the name Tahltan because it is more common in linguistic circles, and employ the same practice with other Northern Athabaskan language names. However, we refer our readers to the language maps of First Peoples' Cultural Council (maps.fphlcc.ca) and First 
Voices (www.firstvoices.com) for more information on how native groups may prefer to refer to their languages.

\section{Shifts and mergers in Northern Athabaskan}

To understand present-day Tahltan, we must first understand a set of sound changes that have been proposed to account for Northern Athabaskan languages. The inventory in (1) represents the reconstructed consonants of Proto-Athabaskan (Krauss 1964; Krauss \& Golla 1981; Leer 1979; Rice 1994). The system of contrasts in (1) is usually described in stems, which are canonically monosyllabic and typically have $\mathrm{CV}(\mathrm{C})$ prosodic structure. The full range of consonants was available stem-initially in Proto-Athabaskan (PA), but stem-finally the three-way laryngeal contrast in stops was neutralized to a two-way contrast between voiceless unaspirated stops and ejectives. The retroflex-palatal series, reconstructed originally in Krauss (1964) as a fronted velar series with a labial component, ${ }^{*} k^{w}$, are reconstructed to explain the $t s$ : $t r$ opposition in Alaskan languages like Minto and Ingalik. Laterals $t$ and $l$ are typically grouped with fricatives because they often pattern with fricatives in voicing alternations.

\section{(1) Proto-Athabaskan consonants}

\begin{tabular}{|c|c|c|c|c|c|c|c|c|}
\hline Dbstruents & & & & & & & & \\
\hline vls unasp stop & $\begin{array}{l}\text { dental } \\
\text { d }\end{array}$ & $\begin{array}{l}\text { lateral } \\
\mathrm{dl}\end{array}$ & $\begin{array}{l}\text { alveolar } \\
\mathrm{dz}\end{array}$ & $\begin{array}{l}\text { palatal } \\
\text { dž }\end{array}$ & $\begin{array}{l}\text { retro-pal } \\
\mathrm{d} \check{z}^{\mathrm{r}}\end{array}$ & $\begin{array}{l}\text { velar } \\
\text { g }\end{array}$ & $\begin{array}{l}\text { uvular } \\
\text { G }\end{array}$ & $\begin{array}{l}\text { glottal } \\
?\end{array}$ \\
\hline vls asp stop & $\mathrm{t}$ & $\mathrm{tt}$ & ts & tšs & tšs $\breve{r}^{2}$ & $\mathrm{k}$ & $q$ & \\
\hline ejective stop & $t^{\prime}$ & tt' & ts' & tšs' & tšs ${ }^{\prime} r$ & 1 ' & $\mathrm{q}$ & \\
\hline vls fricative & & 1 & $\mathrm{~s}$ & $\check{\mathrm{S}}$ & $\breve{S}^{\mathrm{r}}$ & $\mathrm{x}$ & $\chi$ & $\mathrm{h}$ \\
\hline $\mathrm{vd}$ fricative & & 1 & $\mathrm{Z}$ & Ž & $\check{Z}^{r}$ & $y$ & $\mathrm{R}$ & \\
\hline
\end{tabular}

\section{Sonorants}

$\begin{array}{lll}\text { w } & & y \\ m & n & y\end{array}$

No descendent of Proto-Athabaskan retains the entire set of consonants. The dental, lateral, and glottal series tend to be stable historically. The other five place series, boxed in (1), have undergone several shifts and mergers that are often used as features for classifying Northern Athabaskan languages. These sound changes usually apply to all obstruents in the series, and not in piecemeal fashion. The most important of these changes for our study is a chain shift dubbed the Great Northern Series Shift, described below.

(2) Great Northern Series Shift (=GNSS, after Leer 1996)

Stage 1. Fronting of the affricate series: alveolar obstruents shift to interdentals and palatals shift to alveolar place, e.g., *ts $>\mathrm{t} \theta, *$ tš $>$ ts.

Stage 2. Fronting of palatals and uvular onsets: velars (a.k.a. fronted velars) become palatals and uvulars become velars in syllable onsets, e.g., ${ }^{*} \mathrm{k}>\mathrm{t} \check{\mathrm{s}}, \mathrm{q}>\mathrm{k} / \sigma[\ldots$. 
Retroflex palatals had merged with palatals in most languages prior to the GNSS, so they are generally fronted as palatals in stage 1. A few Northern Athabaskan languages only underwent stage 1, e.g., the Alaskan languages Lower Koyukon and Holikachuk, but the majority underwent both stages. Northern Athabaskan languages can be further cross-classified by mergers affecting front (alveolar and palatal) and back (palatal and velar) place classes. These differences are shown below in (3) with a sampling of related languages. The languages below are chosen because of their potential contact with Tahltan, either through geographic proximity or known ancestral ties. We will return to these relationships in section 5. Kaska, for example, continues the five place classes as four: $t \theta / t s / t s / t \grave{s} / k$, merging PA palatals and retroflex palatals to $t s$ and shifting all consonants forward via the GNSS. Sekani is likewise believed to have undergone both stages, but the two front classes resulting from stage 1 of the GNSS shift merged into a single alveolar place: $* t s / t \check{s} / t s^{r} / k / q>t s / t s / t s / t \check{s} / k$. Witsuwit'en, on the other hand, only underwent stage 1 of the GNSS, as shown by velar and uvular reflexes, but it seems to share with Sekani and other neighboring languages the merger of $* t \theta t s>t s$.

(3) Structural features of Northern Athabaskan languages in contact with Tahltan

\begin{tabular}{|c|c|c|c|c|c|c|c|}
\hline & Tone & Obst $]_{\mathrm{St}}$ & $\left.\mathrm{C}^{\prime}\right]_{\mathrm{St}}$ & $* \mathrm{ts} / \mathrm{ts}>\mathrm{ts}$ & $* \mathrm{tš} / \mathrm{ts} \check{s}^{r}>\mathrm{ts} \check{s}$ & $* \mathrm{ts} / \mathrm{k}>\mathrm{t} \check{\mathrm{s}}$ & $* \mathrm{ts} / \mathrm{tš} / \mathrm{ts̆}^{\mathrm{r}} / \mathrm{k} / \mathrm{q}$ \\
\hline "No. Tutchone & high & no & NA & no & yes & $\overline{\text { no }}$ & $\overline{t \theta} \theta$ ts ts tš k \\
\hline So. Tutchone & low & no & NA & no & yes & no & $\mathrm{t} \theta$ ts ts tš $\mathrm{k}$ \\
\hline Tagish & low & no & NA & yes & yes & no & ts ts ts ts ${ }^{\mathrm{y}} \mathrm{k}$ \\
\hline Tsetsaut & absent & no & NA & yes & no & no & ts ts pf tš k \\
\hline Kaska & high & yes & no & no & yes & no & $\mathrm{t} \theta$ ts ts tš $\mathrm{k}$ \\
\hline Tahltan 1 & (low) & yes & no & no & yes & no & t $\theta$ ts ts tš $k$ \\
\hline Tahltan 2 & (low) & yes & no & no & yes & yes & ts tš tš tš k \\
\hline Sekani & low & yes & no & yes & yes & no & ts ts ts tš k \\
\hline HW Beaver & low & yes & no & yes & yes & no & ts ts ts tš k \\
\hline D/B Beaver & high & yes & no & yes & yes & no & $\mathrm{t} \theta$ ts ts tš $\mathrm{k}$ \\
\hline Witsuwit'en & absent & yes & no & yes & yes & no & ts ts ts $\mathrm{k} \mathrm{q}$ \\
\hline
\end{tabular}

Where does Tahltan fit into the picture? Tahltan is similar to its neighbors to the north (Kaska) and east (Beaver, Sekani) in its retention of stem final obstruents. This is in contrast to Tahltan's neighbors to the north (Tutchone, Kutchin) and west (Tagish, Tsetsaut) that neutralized stem-final obstruents to default coronal and velar stops. But like Tagish and Southern Tutchone, and unlike Kaska, Tahltan developed low-marked tone. See Krauss and Golla (1981) for a more comprehensive analysis of these features and important references, and the following works for more detailed accounts of individual languages: Moore (2002) on Kaska, Hargus (1985) on Sekani, Randoja (1989) on Beaver, and Hargus (2007) on Witsuwit'en.

The development of affricates in Tahltan is less clear. The data supporting the first pattern, Tahltan 2 in Table 1 (Krauss \& Golla 1981; Story 1975), was collected by Kenneth Hale and Geoff O'Grady in 1965 from a Tahltan elder, Pete Henyu. Mr. Henyu was 79 at the time of the recording, so the data he provided illustrates the language of an elder born 14 years before the turn of the twentieth century. Since this work, two studies have collected data that support a different analysis (Tahltan 1). Hardwick (1984) re-examines the development of affricates with data from several elders from the Telegraph Creek area and argues for a more conservative historical analysis 
$* t s / t \check{s} / t \check{s}^{r} / k / q>t \theta / t s / t s / t \check{s} / k$, retaining the distinction between $* t \check{s}: k$ as $t s: t \check{s}$. Nater (1989) comes to a similar conclusion, based on his extensive study of Tahltan spoken in Iskut.

The conservative analysis of Hardwick and Nater has informed linguistic documentation work conducted in the 1980's and 1990's, including the children's dictionary and the creation of an orthography (Carter \& Council 1994; Leer 1985). The interdentals, which are not posited in Story's analysis, are used in the standard pronunciations of many words. The contemporary Tahltan sound inventory given below with phonetic symbols reflects this standard (see Carter (1994) and Alderete and Blenkiron (2014) for the conversions of these sounds to the Tahltan orthography).

(4) Tahltan consonants

\begin{tabular}{|c|c|c|c|c|c|c|c|c|c|}
\hline & labial & dental & lateral & interdental & alveolar & palatal & velar & uvular & glottal \\
\hline vls & & $\mathrm{d}$ & $\mathrm{dl}$ & dð & $\mathrm{dz}$ & $\mathrm{dž}$ & $g g^{w}$ & & $?$ \\
\hline vls asp & & $\mathrm{t}$ & $\mathrm{t} 1$ & $\mathrm{t} \theta$ & ts & ts & $\mathrm{k} \mathrm{k}^{\mathrm{w}}$ & (q) & \\
\hline ejective & & $\mathrm{t}^{\prime}$ & tt' & $\mathrm{t} \theta^{\prime}$ & ts' & ts' & $\mathrm{k}^{\prime}$ & (q') & \\
\hline vls fric & & & 1 & $\theta$ & $\mathrm{s}$ & $\mathrm{s}$ & $\mathrm{x} \quad \mathrm{x}^{\mathrm{w}}$ & & $\mathrm{h}$ \\
\hline vd fric & & & 1 & ð & $\mathrm{z}$ & $\mathrm{z}$ & $\gamma \gamma^{\mathrm{w}}$ & & \\
\hline nasal & $\mathrm{m}$ & & & & $\mathrm{n}$ n $\mathrm{n}$ ' & & & & \\
\hline norant & $\mathrm{w}$ & & & & & $\mathrm{y}$ & & & \\
\hline
\end{tabular}

Following standard practice in Athabaskan, the aspirated/unaspirated distinction is written $t: d$ and $k$ : $g$, though $b$ is actually a voiced stop (Bob 1999). Also, uvulars seem to be more characteristic of an older generation, as many speakers today have merged them with the corresponding velars and some Tahltan uvulars may have come from Tlingit (Hardwick 1984; Nater 1989).

This background seems to cast some doubt on Story's original analysis * $t s / t \check{s} / t \check{s}^{r} / k>t s / t \check{s} / t \check{s} / t s^{2}$. Furthermore, the first author was given a copy of the Pete Henyu tapes by Ken Hale and he has played them to several Tahltan elders. Many elders have commented on the unusual nature of Mr. Henyu's speech. It is described as having some unfamiliar characteristics, including its rhythm, use of particles, and double subject marking. If it is true that this pattern is not representative of a larger group, then this finding would weaken somewhat the claim that the different mergers found in the Tagish/Tahltan/Kaska complex are superficial in nature, and do not reflect deep structural differences among these languages. The developments $* t s / t \check{s} / t \check{s}^{r} / k / q>t \theta / t s / t s / t \check{s} / k$ into Tahltan would seem to be just one of a number of features it has in common with Kaska and other languages further east, including Sekani and Beaver dialects, a point emphasized in Hardwick (1984). On the other hand, if we find further evidence for the Henyu system within Tahltan, this would provide even stronger evidence for the superficial nature of the series mergers and shifts. It would show that the variation attested in the larger language complex exists at the subdialectal level as well. It is against this background that we investigate the variation and developments in the obstruent systems in more detail.

\section{Stem phonotactics}

Many of the structural features used to relate Tahltan to its neighbours, like the development of affricates, have been based on somewhat limited data. In what follows, we situate the obstruent phonology within a quantitative analysis of stem phonotactics. Such an analysis is warranted in its own right, because of the increasing importance of probabilistic effects in phonology (e.g., 
Pierrehumbert (2003)). An account of the frequencies of phonological segments also provides new insight into some of the developments discussed in section 5.

To describe stem phonotactics, we constructed a stem list from a larger wordlist of 1,038 words created from our own fieldwork, three other primary linguistic descriptions of the language ((Hardwick 1984; Nater 1989; Nater 2006), and the children's dictionary (Carter \& Council 1994). We excluded grammatical morphemes and function words, and also adjectives and adverbs, which are often morphologically complex. This resulted in a list of 455 stems consisting of nouns, verbs, and postpositions. Stems in Athabaskan languages are usually monosyllabic, so polysyllabic words had to be examined for morphological complexity, including looking for known prefixes and the stem increment $-e$. For many disyllabic words, removing these morphemes resulted in a CVC stem, which was included in the stem list as such.

The tables in (5) give the frequencies of stems sorted by the number of syllables and their CV structure. These frequencies show that there are several disyllabic stems, e.g., kene $\theta$ 'raft', but the overwhelming majority of stems are monosyllabic (92.7\%). As for stem shape, most stems end in a consonant $(81.5 \%)$.

(5) a. Stem size frequencies

\begin{tabular}{|l|l|l|}
\hline 1 & 2 & 3 \\
\hline 422 & 29 & 4 \\
\hline
\end{tabular}

b. Stem shape frequencies

\begin{tabular}{|l|l|l|l|l|}
\hline CV & CVV & CVC & CVVC & CVCC \\
\hline 11 & 67 & 220 & 121 & 3 \\
\hline
\end{tabular}

These facts support the monosyllabic CVC structure as the canonical stem shape. They also confirm the (near total) lack of clusters stem-finally, an important areal feature characteristic of neighboring Northern Athabaskan languages like Kaska and Sekani.

Moving to the distribution of consonants, the type frequencies of consonants are given below, sorted by stem-initial and final position. Given the rarity of certain sounds, and transcription inconsistency across sources, we had to collapse a few sounds into a single category. For example, there are only three instances of rounded velars, so these were merged with their corresponding unrounded velars. Three instances of $\chi$ were likewise grouped with the voiceless velar fricative. The collapsing of these categories is motivated empirically because rounded velars were either lost or nearly so, and uvulars are replaced by corresponding velars by most speakers (Nater 1989). Finally, voiceless and glottalized nasals were collapsed with the alveolar nasal, but again, there were only a handful of these. The true counts can be recovered with the above information, but we wish to have a good count of the place of articulation classes, which does not change with these adjustments.

(6) Consonant frequencies

a. Labial

\begin{tabular}{|l|l|l|l|}
\hline & $\mathrm{b}$ & $\mathrm{m}$ & $\mathrm{w}$ \\
\hline \hline initial & 12 & 5 & 0 \\
\hline final & 0 & 4 & 2 \\
\hline total & 12 & 9 & 2 \\
\hline
\end{tabular}

\section{b. Dental}

\begin{tabular}{|l|l|l|l|}
\hline & $\mathrm{d}$ & $\mathrm{t}$ & t' \\
\hline \hline initial & 51 & 27 & 23 \\
\hline final & 16 & 33 & 0 \\
\hline total & 67 & 60 & 23 \\
\hline
\end{tabular}


c. Interdental

\begin{tabular}{|l|l|l|l|l|l|}
\hline & $\mathrm{d} \delta$ & $\mathrm{t} \theta$ & $\mathrm{t} \theta^{\prime}$ & $\partial$ & $\theta$ \\
\hline \hline initial & 1 & 11 & 13 & 16 & 8 \\
\hline final & 1 & 6 & 0 & 1 & 23 \\
\hline total & 2 & 17 & 13 & 17 & 31 \\
\hline
\end{tabular}

e. Alveolar

\begin{tabular}{|l|l|l|l|l|l|l|}
\hline & $\mathrm{dz}$ & ts & ts' & $\mathrm{z}$ & $\mathrm{s}$ & $\mathrm{n}$ \\
\hline \hline initial & 7 & 12 & 10 & 2 & 8 & 7 \\
\hline final & 3 & 6 & 0 & 5 & 24 & 56 \\
\hline total & 10 & 18 & 10 & 7 & 32 & 63 \\
\hline
\end{tabular}

g. Velar

\begin{tabular}{|l|l|l|l|l|l|}
\hline & $\mathrm{g}$ & $\mathrm{k}$ & $\mathrm{k}^{\prime}$ & $\mathrm{x}$ & $\mathrm{g}$ \\
\hline \hline initial & 21 & 15 & 23 & 13 & 14 \\
\hline final & 2 & 7 & 0 & 4 & 1 \\
\hline total & 23 & 22 & 23 & 17 & 15 \\
\hline
\end{tabular}

d. Lateral

\begin{tabular}{|l|l|l|l|l|l|}
\hline & $\mathrm{dl}$ & $\mathrm{t} 1$ & $\mathrm{t} \mathbf{l}^{\prime}$ & 1 & $\mathrm{1}$ \\
\hline \hline initial & 7 & 4 & 15 & 18 & 9 \\
\hline final & 3 & 4 & 0 & 7 & 44 \\
\hline total & 10 & 8 & 15 & 25 & 53 \\
\hline
\end{tabular}

f. Palatal

\begin{tabular}{|l|l|l|l|l|l|l|}
\hline & dž & ť̌ & ťs' & ž & š & y \\
\hline \hline initial & 6 & 23 & 5 & 0 & 0 & 16 \\
\hline final & 3 & 3 & 0 & 1 & 8 & 0 \\
\hline total & 9 & 26 & 5 & 1 & 8 & 16 \\
\hline
\end{tabular}

h. Glottal

\begin{tabular}{|l|l|l|}
\hline & ? & $\mathrm{h}$ \\
\hline \hline initial & 21 & 0 \\
\hline final & 38 & 41 \\
\hline total & 59 & 41 \\
\hline
\end{tabular}

For this data, it is clear that certain sounds have a much higher frequency than others. We sort consonants arbitrarily into bins based on multiples of 20 below, to give a rough sense of the relative frequencies.

(7) Frequency classes (in 455 stems)

\begin{tabular}{|l|l|l|l|}
\hline High $(n>40)$ & Medium $(20<n<39)$ & Low $(3<n<19)$ & Very rare $(\mathrm{n} \leq 2)$ \\
\hline$t d t n ? h$ & $\theta t^{\prime} l s t \check{s} g k k^{\prime}$ & $\begin{array}{c}b m t \theta t \theta^{\prime} \partial d z t s t s^{\prime} \\
d l t t t t^{\prime} z d \check{z} t \check{s}^{\prime} s^{\prime} y x_{\gamma}\end{array}$ & $w d \partial z \check{z}$ \\
\hline
\end{tabular}

These counts must be qualified by restrictions on position. $h$ has a rather high frequency, but it only occurs in stem-final position. On the other hand, $\check{s}$ and $\check{z}$ never occur stem-initially. These sounds, especially $\check{z}$, are questionable as phonemes of the language because they were lost steminitially (see Hardwick (1984)), and may be predictable from the regular rule of consonant harmony (Hardwick 1984; Shaw 1991). There are also sounds that never occur stem-finally: $b, y$, and ejectives as a class. These frequencies show that the two-way distinction between plain and ejective stops in Proto-Athabaskan stem-finals has been lost in Tahltan, a fact that is also consistent with stem-finals in many of Tahltan's neighbors to the north and east (see (3)). The absence of stem-final $b$ is not a surprise, however, because it is generally the reflex of stem-initial $* w$ (Krauss \& Leer 1981). We also note that velars as a class have medium frequency, but they are clearly preferred stem-initially.

The counts shown below of the anticipated reflexes of PA obstruents give a sense of the robustness of the different affricate classes. Most of the affricates and fricatives have medium to low frequency, with the phoneme $t \check{s}$ emerging as the clear leader. Four cases have very low counts: $d \delta$, which is rare both stem-initially and finally, $z$, also rare in general, and the palatal fricatives, which never give an appearance stem-initially. 
(8) Stem-initial affricates

\begin{tabular}{|ll|ll|ll|}
\hline \multicolumn{2}{|c|}{$*_{\mathrm{ts}}$} & \multicolumn{2}{c|}{$*$ tš } & \multicolumn{2}{c|}{$*_{\mathrm{k}}$} \\
\hline \hline $\mathrm{t} \theta$ & 11 & ts & 12 & tš & 23 \\
\hline $\mathrm{t} \theta$ & 13 & ts' & 10 & tš & 5 \\
\hline $\mathrm{d} ð$ & 1 & $\mathrm{dz}$ & 7 & $\mathrm{~d} \check{z}$ & 6 \\
\hline$\theta$ & 8 & $\mathrm{~s}$ & 8 & s & 0 \\
\hline $\mathrm{d}$ & 16 & $\mathrm{z}$ & 2 & $\mathrm{z}$ & 0 \\
\hline
\end{tabular}

Finally, the co-occurrence table below documents the interaction of the place classes in stems (excluding glottals). In this table, rows and columns indicate stem-initials and stem-finals, respectively.

(9) Co-occurrence of consonants

\begin{tabular}{|c|c|c|c|c|c|c|c|}
\hline & & dent & lat & int-dent & alv & pal & vel \\
\hline dental & $d t t^{\prime}$ & 5 & 14 & 8 & 10 & 3 & 2 \\
\hline lateral & $d l t t t^{\prime} l t$ & 9 & 5 & 1 & 2 & 0 & 4 \\
\hline interdental & $d ð t \theta t \theta^{\prime}$ ১ $\theta$ & 11 & 11 & 7 & 0 & 0 & 1 \\
\hline alveolar & $d z t s^{\prime} z s n$ & 4 & 2 & 0 & 8 & 0 & 2 \\
\hline palatal & $d \check{z} t \check{s} t \check{s}{ }^{\prime} \check{z} \check{s} j$ & 4 & 7 & 0 & 0 & 9 & 1 \\
\hline velar & $g k k^{\prime} x_{\gamma}$ & 11 & 11 & 11 & 13 & 1 & 5 \\
\hline
\end{tabular}

While most series freely combine with one another, the coronal place classes referred to by the coronal harmony rule (Hardwick 1984; Shaw 1991), i.e., interdental, alveolar, and palatal, do not freely co-occur. As shown in the boxed region, same-place coronal categories are not restricted, but different-place combinations are categorically avoided, which is clearly significant. The different-place combinations are of course just those combinations that would be ruled out as disharmonic roots. The lateral and dental series are not restricted in this way, consistent with their transparent nature. These restrictions are expected synchronically if coronal harmony is active in roots, but they are also predicted historically, because Proto-Athabaskan stems have been shown to avoid certain different-place combinations, including ${ }^{*} t s$ and $* t s ̌$ (Krauss 1964).

\section{Development of affricates}

How did the Proto-Athabaskan affricate series develop into present-day Tahltan, and what is the range of variation among speakers? To answer this question, we constructed a 46-word questionnaire designed to elicit the four principal place series (alveolar, palatal, palatal-retroflex, and velar) in stem-initial obstruents. The questionnaire was based on the PA reconstructions given in the appendix and shown in the table headers below. The data were collected by the first author in 1999 and 2000 with seven fluent speakers. In each interview, he attempted to gain an initial purchase of the data, checking for non-cognate forms and pronunciation detail. Once the facts were reasonably clear, a second run through the questionnaire was recorded with a tie-clip lavaliere microphone. Four of the native speakers had either been raised in Telegraph Creek or had strong associations with this community. The remaining three speakers were from Iskut. The age of the native speakers ranged from 59 to 83, so these speakers were born between 1917 and 1941. To confirm the transcriptions, each interview was checked by either the second or third author. 
Of our seven consultants, two pairs were couples and they wished to be present at their spouse's interview. Interestingly, both couples demonstrated different obstruent patterns, even when presented with the rather salient differences by their spouse. These differences were noted on more than one occasion by the consultants, demonstrating that they were consciously aware of at least some of the differences.

The next three tables illustrate the data collected in characteristic speaker profiles. As expected from Hardwick (1984) and Nater (1989), the predominant pattern was a merger of the two palatal series and a wholesale shift forward in the mouth. This is the standard obstruent system used by language practitioners and linguists. This pattern is illustrated below in (10) with the speech of an Iskut elder. He was born in Telegraph Creek on the reserve across from Dry Town, but immigrated to Iskut later and attended school there for ten years. This elder had historical ties with Bear Lake Sekani people and therefore may have been influenced by speakers of Sekani. However, the same conservative pattern of retaining a three-way contrast is also found in three other speakers, two of whom have rather different backgrounds, including attending school in Telegraph Creek and having significant contact with Tlingit.

(10) Speaker profile I: the $t \theta / t s / t s / t s ̌ s$ standard (representative of four speakers)

\begin{tabular}{|c|c|c|c|c|}
\hline & $*_{\mathrm{ts}}>\mathrm{t} \theta$ & $*$ ts $>$ ts & $*_{\mathrm{ts}}{ }^{\mathrm{r}}>\mathrm{ts}$ & $* \mathrm{k}>\mathrm{tš}$ \\
\hline $\begin{array}{l}\text { vls } \\
\text { asp }\end{array}$ & $\begin{array}{l}\text { t } \theta \mathrm{e}: \text { 'stone' } \\
\text {-t } \theta \text { i? 'head' } \\
\text { t } \theta \text { en' 'meat' } \\
\operatorname{det} \theta \text { or 'yellow' }\end{array}$ & $\begin{array}{l}\text { tsa? 'beaver' } \\
\text {-tsiye 'grandfather' } \\
\text { detsi:ts, detsi:dzi 'red' }\end{array}$ & $\begin{array}{l}\text { tsà:? 'excrement' } \\
\text { tsets 'firewood' } \\
\text {-tsex 'cry' }\end{array}$ & $\begin{array}{l}\text {-latšıne 'wrist' } \\
\text {-ketšıne 'ankle' } \\
\text { tša: 'rain' } \\
\text {-laštšo: 'thumb' }\end{array}$ \\
\hline $\begin{array}{l}\text { vls } \\
\text { eject }\end{array}$ & $\begin{array}{l}\text { t } \theta \text { 'a? 'plate, dish' } \\
\text { t } \theta \text { 'è: 'thread' } \\
\text { t } \theta \text { 'enh 'bone' } \\
\text { t } \theta \text { 'a:tl 'diaper' }\end{array}$ & $\begin{array}{l}\text { ts'ah 'hat' } \\
\text { ts'ede 'blanket' } \\
\text { ts'u: 'spruce' } \\
\text {-ts'i?e 'guts' }\end{array}$ & $\begin{array}{l}\text { nats'ih 'wind } \\
\text { blows' } \\
\text {-ts'əse 'kidney' }\end{array}$ & $\begin{array}{l}\text { tš'ohe 'porcupine quills' } \\
\text { tšide 'veins, gristle' }\end{array}$ \\
\hline unasp & $\begin{array}{l}\text { dðet 'mountain } \\
\text { (over-hanging bluff)' }\end{array}$ & $\begin{array}{l}\text { dzeh len 'pitch' } \\
\text {-dzeke 'inner ear' }\end{array}$ & $\begin{array}{l}\text { dzene } \theta \text { 'day' } \\
\text {-dze:? 'heart' } \\
\text {-dza:ke 'shin' }\end{array}$ & $\begin{array}{l}\text { nedžıt 'he's scared' } \\
\text { tšošk'a?e 'Canadian Jay' } \\
\text { dža:ni 'here' }\end{array}$ \\
\hline fric & $\begin{array}{l}\text {-ðet 'liver' } \\
\text {-ðà:t 'mouth' } \\
\text { Өa: 'sand' }\end{array}$ & sini 'I/me' & $\begin{array}{l}\text { sa: 'sun' } \\
\text { sek 'saliva' }\end{array}$ & 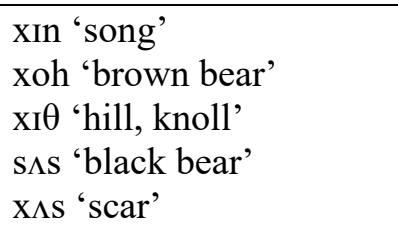 \\
\hline
\end{tabular}

While most of the place/manner classes shifted forward, the velar fricatives did not; see e.g., 'song' and 'brown bear'. Our reconstructed velar fricatives are 'front velars' and not uvulars (see appendix), because uvulars would not be expected to shift to palatals. While correspondences with 'black bear' are generally irregular in Athabaskan (Huld 1983), the observed form, sıs, is interesting because if the stem-initial had shifted as expected, i.e., *xə̌s > š $s$, it would have produced a disharmonic root, contrary to the regular rules of coronal harmony (Hardwick 1984; Shaw 1991). As we saw in section 4, Tahltan does not have any stems beginning with palatal fricatives, so it must be that $*_{s}$ shifted forward, e.g., 'sun', 'saliva', but the velar fricatives did not, leaving this slot empty. 
There is a subtle variation on this pattern that relates to the next speaker profile below. The speech of a Telegraph Creek elder is broadly similar to profile I, but retains the PA palatals in stem-initial aspirated stops. Thus, instead of the alveolar affricates shown above in (10), this speaker says $t \check{s} a$ ? 'beaver', -tšiye 'grandfather', $t s ̌ i h$ 'red ochre', and $t \check{s}$ etšs 'firewood', and varies between -tsex and -tšex for 'cry', cf. tsà:? 'excrement'. It seems that in this case the shift of the palatals to alveolars only occurred in unaspirated stops, ejectives, and fricatives.

This piecemeal pattern is of interest because another speaker from Telegraph Creek has the same pattern with all the palatal stops, with a few exceptions. This elder's speech is illustrated below in (11). She was 83 at the time of the interview, the oldest of our consultants, and was born in Shesley, which is a Kaska-speaking area of British Columbia. However, she had strong associations with Tahltan people from Telegraph Creek. This elder has also had significant contact with both Tlingit and Haida.

(11) Speaker profile II: $t \theta / t \check{s} / t \grave{s} / t \check{s}$

\begin{tabular}{|c|c|c|c|c|}
\hline & $*_{\mathrm{ts}}>\mathrm{t} \theta$ & $*_{\mathrm{ts̆}}>\mathrm{t} \check{\mathrm{s}}$ & $*_{\mathrm{t} \breve{s}^{\mathrm{r}}}>\mathrm{t} \check{\mathrm{s}}$ & $*_{\mathrm{k}}>\mathrm{tš}$ \\
\hline $\begin{array}{l}\text { vls } \\
\text { asp }\end{array}$ & $\begin{array}{l}\text { t } \theta \mathrm{e}: \text { 'stone' } \\
\text {-t } \theta \mathrm{i} \text { ? 'head' } \\
\text { t } \theta \mathrm{en} \text { ' 'meat' } \\
\operatorname{det} \theta \text { or 'yellow' }\end{array}$ & $\begin{array}{l}\text { tša? 'beaver' } \\
\text {-tšiye 'grandfather' }\end{array}$ & $\begin{array}{l}\text { tšà:? 'excrement' } \\
\text { tšetš 'firewood' } \\
\text { eš-tšai 'I cry' }\end{array}$ & $\begin{array}{l}\text {-latšine 'wrist' } \\
\text {-ketšine 'ankle' } \\
\text { tša: 'rain' } \\
\text {-laštšo: 'thumb' }\end{array}$ \\
\hline $\begin{array}{l}\text { vls } \\
\text { eject }\end{array}$ & $\begin{array}{l}\text { t } \theta \text { 'a? 'plate, dish' } \\
\text { t } \theta \text { 'è: 'thread' } \\
\text { t } \theta \text { 'enh 'bone' }\end{array}$ & $\begin{array}{l}\text { tš'ede 'blanket' } \\
\text { tš'u: 'spruce' } \\
\text {-tš'i?e 'guts' } \\
\text { cf. ts'ah 'hat' }\end{array}$ & cf. -ts'ese 'kidney' & $\begin{array}{l}\text { tš'ohe 'porcupine quills' } \\
\text { tšide 'veins, gristle' }\end{array}$ \\
\hline unasp & dðel 'mountain' & $\begin{array}{l}\text {-džešbıtle 'ear' } \\
\text { džè:tl'en 'pitch' }\end{array}$ & $\begin{array}{l}\text {-dže: 'heart' } \\
\text { cf. -dzodze 'shin' }\end{array}$ & $\begin{array}{l}\text { nedžit 'he's scared' } \\
\text { tšo:sk'a?e 'Canadian Jay' } \\
\text { dža:n 'here' }\end{array}$ \\
\hline fric & $\begin{array}{l}\text {-ðet 'liver' } \\
\text {-ðà:t 'mouth, } \\
\text { throat' } \\
\text { Өa: 'sand' }\end{array}$ & sini 'I/me' & sa: 'sun' & (data unavailable) \\
\hline
\end{tabular}

We list 'hat', 'kidney', and 'shin' as exceptions here (they shifted instead of retaining the ancient palatal), but we actually find them difficult to classify. They might best be described as intermediate between $t s$ and $t \grave{s}$. We also note that this elder has particularly clear examples of lowmarked tone, e.g., 'thread' and 'mouth', as well as a reluctance for lax $I$ in words like 'wrist' and ' $\mathrm{I} / \mathrm{me}$ ', which is found in most other speakers.

The third pattern of development is similar to profile I, except the $* t s$ series does not shift forward to interdentals. Thus, this speaker lacks interdentals altogether and simply opposes $t s: t s^{\circ}$ This elder was 73 at the time of the interview and was married to a speaker with an obstruent system similar to profile I. She was multi-lingual, with fluent or near fluent command of English, French, Tahltan, as well as Cree (her mother was a Cree native speaker) and Sekani (her father spoke Sekani). It is not known at what point she learned Tahltan, but her fluency was confirmed in the interview. 
(12) Speaker profile III: $t s / t s / t s / t \breve{s}$

\begin{tabular}{|c|c|c|c|c|}
\hline & $*_{\mathrm{ts}}>\mathrm{ts}$ & $* t s ̌ s$ & $*_{\mathrm{t} \breve{\mathrm{s}}^{\mathrm{r}}>\mathrm{ts}}$ & $* \mathrm{k}>\mathrm{tšs}$ \\
\hline $\begin{array}{l}\text { vls } \\
\text { asp }\end{array}$ & $\begin{array}{l}\text { tse: 'stone' } \\
\text {-tsi? 'head' } \\
\text { tsen' 'meat' } \\
\text { detsor 'yellow' }\end{array}$ & $\begin{array}{l}\text { tsa? 'beaver' } \\
\text {-tsiye 'grandfather' } \\
\text { tsih 'red ochre' }\end{array}$ & $\begin{array}{l}\text { tsà:? 'excrement' } \\
\text { tsets 'firewood' } \\
\text {-tsex 'I cry' }\end{array}$ & $\begin{array}{l}\text {-latšıne 'wrist' } \\
\text {-ketšıne 'ankle' } \\
\text { tša: 'rain' } \\
\text {-laštšo: 'thumb' }\end{array}$ \\
\hline $\begin{array}{l}\text { vls } \\
\text { eject }\end{array}$ & $\begin{array}{l}\text { ts'a? 'plate, dish' } \\
\text { ts'è 'thread' } \\
\text { ts'enh 'bone' } \\
\text { ts'a:tl 'diaper' }\end{array}$ & $\begin{array}{l}\text { ts'ah 'hat' } \\
\text { ts'ede 'blanket' } \\
\text { ts'u: 'spruce' } \\
\text {-ts'i?e 'guts' }\end{array}$ & $\begin{array}{l}\text { nats'ih 'wind blows' } \\
\text {-ts'ese 'kidney' }\end{array}$ & \\
\hline unasp & $\begin{array}{l}\text { eya dzele 'high } \\
\text { mountain' }\end{array}$ & $\begin{array}{l}\text { dzehe 'pitch' } \\
\text {-dzeke 'inner ear' }\end{array}$ & $\begin{array}{l}\text { dzene日 'day' } \\
\text {-tse? 'heart' } \\
\text {-dzada 'shin' }\end{array}$ & $\begin{array}{l}\text { nedžit 'he's scared' } \\
\text { dža:n 'here' }\end{array}$ \\
\hline fric & $\begin{array}{l}\text {-zet 'liver' } \\
\text {-zat 'mouth } \\
\text { sa: 'sand' }\end{array}$ & sini 'I/me' & $\begin{array}{l}\text { sa: 'sun' } \\
\text { sek 'saliva' }\end{array}$ & $\begin{array}{l}\text { XIn 'song' } \\
\text { XIS 'hill, knoll' } \\
\text { s } \Lambda \text { s 'black bear' } \\
\text { X } \Lambda \text { s 'scar' }\end{array}$ \\
\hline
\end{tabular}

The table below lists the results of our survey with profiles I-III, and compares them with the speech of Pete Henyu (IV), who would have been 114 in year 2000 (approximate date of interviews), or two generations older than most of our consultants. The three patterns differ in the number of resulting place contrasts (three vs. two) and the extent of the shifts. It is not really possible to collapse the profiles by community, as profile I has representatives, even with this small sample, from both communities.

(13) Individual differences in shifts ( $\mathrm{I}=\mathrm{Iskut}, \mathrm{TC}=$ Telegraph Creek)

\begin{tabular}{lllllll} 
profile & community & age at $2 \mathrm{M}$ & $*$ ts & $*$ tš & $*_{\text {tšr }}$ & $* \mathrm{*}$ \\
\hline \hline I & I & 70 & t $\theta$ & ts & ts & tš \\
I & I & 78 & t $\theta$ & ts & ts & tš \\
I & TC & 59 & t $\theta$ & ts & ts & tš \\
I & TC & 61 & t $\theta$ & ts & ts & tš \\
\hline I-II & TC & 72 & t $\theta$ & tš/ts & tš/ts & tš \\
\hline II & TC & 83 & t $\theta$ & tš & tš & tš \\
\hline III & I & 73 & ts & ts & ts & tš \\
\hline IV & TC & $(114)$ & ts & tš & tš & tš
\end{tabular}

To summarize, in addition to the conservative obstruent system in profile I, and IV known from Pete Henyu's speech, we have uncovered two additional systems: one that resembles Tahltan's neighbors to the south and east with a merger in the front place classes (profile III), and one that appears to merge $t s$ and $t s$ from the conservative system (profile II).

How do these distinct systems fit within the historical perspective established in section 3 ? In Figure 1, we visualize the Tahltan varieties based on accepted developments in Northern Athabaskan languages (see section 3), showing how these variants either relate to neighboring languages or can be derived from one of them. In particular, we show developments from ProtoAthabaskan through both stages of the Great Northern Series Shift and languages that appear to 
have undergone two additional changes: Front Merger, as in Sekani, and Back Merger, which seems to be attested in Tahltan only (see Krauss \& Golla 1981, Figure 1a, for a similar breakdown and partial overlap of component mergers and shifts). This chart is not intended as a tree-based classification showing the accumulation of sound changes in unified groups, but rather as a visual aid illustrating how the Tahltan varieties relate to neighboring languages. Thus, we make no claims about sub-groupings from the relationships depicted below. Indeed, there may be sideways arrows that account for some of the shared mergers that are not depicted here.

GNSS1

$*$ ts $\mathrm{ts}>\mathrm{t} \theta$ ts

GNSS2

*k q > tš k

Front Merger

$* \mathrm{t} \theta$, ts $>$ ts $\mathrm{t} \theta$ ts $\mathrm{k} \mathrm{q}$

Lower Koyukon

Holikachuk

Ingalik

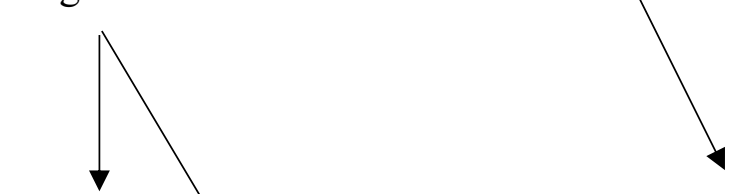

$\mathrm{t} \theta$ ts $\underline{\mathrm{ts}} \underline{\mathrm{k}}$

Tutchone

Kaska

D-B Beaver

Tahltan I
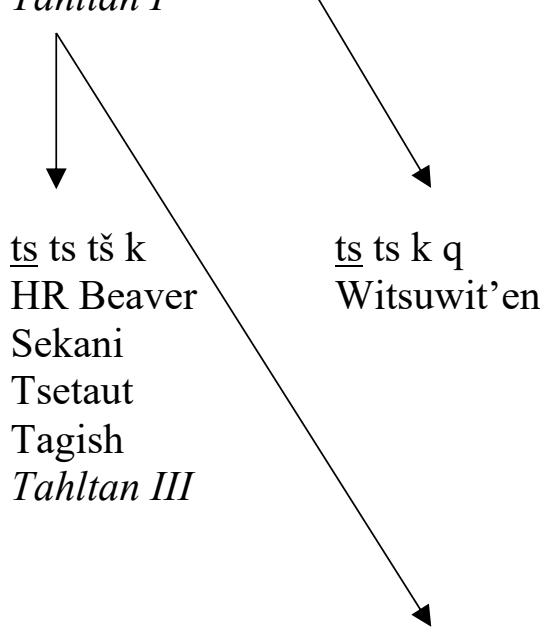

Back Merger

$*_{\mathrm{ts}} \mathrm{tš}>\mathrm{ts}$ $\mathrm{t} \theta$ tš tš $\mathrm{k}$

\section{Tahltan II}

Figure 1. Developments in obstruents observed in Tahltan varieties and its neighbors

From this visualization, we can see clearly how Tahltan varieties relate to other Northern Athabaskan languages through their shared historical phonology. The standard variety (I) is conservative, and so relates to Kaska, Tutchone, and Doig/Blueberry Beaver. That is, Tahltan I 
underwent both stages of the GNSS and no subsequent mergers, thus retaining the four-way place contrast. Tahltan III is the same as Sekani and other neighbors to the south and east. This pattern is likely the result of an influence from Sekani, as the sole speaker of this variety in our survey is also fluent in Sekani, which was the language of her father.

Patterns IV and II are less straightforward. While profile IV is unique in Athabaskan (Krauss \& Golla 1981), it can be accounted if we assume that it only underwent stage 2 of the GNSS. That is, while most languages underwent both stages, and some languages underwent just stage 1 of GNSS, perhaps in this speaker, the GNSS was not a pull chain but simply a shift of velars and uvulars. The only logical alternative is to assume that IV involved all stages of the GNSS, plus Front Merger and Back Merger, but Occam's Razor clearly favors the first solution. Either way, however, it is clear that pattern IV relates to sound changes that must have occurred in Northern Athabaskan.

Finally, II is of interest because it presents two possibilities. It could be derived from Tahltan IV, with a further shift of $* t s>t \theta$. In other words, it could have initially resisted stage 1 of the GNSS, underwent stage 2 with Tahltan IV, followed by a shift of just alveolars (cf. stage 1). The second possibility, shown in Figure 1, is for II to have developed from conservative Tahltan I via Back Merger. While the existence of IV supports the first approach, two facts seem to point to the second solution. First, at least one consultant vacillates between pattern I and II, suggesting a change in progress from I to II, perhaps frozen in the speech of this native speaker because of the general moribund state of the language. Second, Back Merger is supported by the quantitative analysis given in section 4 . The phoneme $t s ̌$ has a strong statistical advantage over $t s$ (8), which can explain at least *ts $t \check{s}>t \grave{s}$ as a well-known type of frequency effect (Blevins 2004; Greenberg $1966 / 2005)$. In pattern II, the merger of $t s$ with high-frequency $t s ̌$ sound could have led the larger stop series, bringing about change to the rest of the alveolars as a class. The fact that the native speaker with I/II behavior shows variation precisely in the voiceless aspirated stops, the statistical leader, supports this analysis. The pattern in profile II, therefore, is not due to contact, because the change seems to be an internal change based on frequency. However, the Tahltan II profile does depend on the foundational change of the GNSS, because it serves as the input to this pattern.

\section{Concluding remarks}

This article has investigated the development of affricates in eight native speakers of Tahltan and found four distinct obstruent systems. In the standard system (I), Proto-Athabaskan obstruents shifted forward in accordance with both stages of the Great Northern Series Shift, $t \theta / t s / t \check{s} / k$, resembling its neighbors to the north (Tutchone, Kaska) and east (Doig/Blueberry Beaver). In another system (III), $t s / t s / t \breve{s} / k$, the two front place classes merged to $t s$, as also observed in neighboring groups to the south and east (Half River Beaver, Sekani, Tsetsaut) and north (Tagish). A third system (II) appears to be a development from I where $t s$ has merged with $t \grave{s}$ as a frequency effect. Finally, IV, while unique in Athabaskan, seems to relate to the rest of the systems by undergoing only stage 2 of the GNSS instead of both stages. Thus, only half of the individual patterns documented here are identical in structure, a fact that underscores the rather dynamic nature of the network of Athabaskan-speaking language groups in this area.

The results also emphasize the importance of individual-level variation and the need to engage with this kind of variation in situating a Northern Athabaskan language with its neighbors. In a sense, both Story's original characterization of Tahltan, and Hardwick and Nater's analysis, are incomplete because they analyze only one facet of this variation. Indeed, given the extent of the 
interaction with neighboring language groups, we would not be surprised if an additional eight speakers uncovered new obstruent systems. These details, and their ties to neighboring groups, are part of the larger picture that characterizes this dynamic language network.

These results also provide some modest practical suggestions for linguistic documentation and language. In particular, they support the existence of a standard obstruent system, similar to that of Kaska. They also give one the tools to analyze three alternate obstruent systems, II, III, IV, that can be recorded in dictionaries as alternate pronunciations of standard forms, following the templates shown in (13). As for teaching, identifying both a standard and alternate obstruent systems may also help language learners grapple with the extensive inter- and intra-speaker variation that exists. We would like to emphasize, however, that adoption of a standard system is not a prescriptive statement that this system is the official version, or "authentic Tahltan", and that other systems are marginal or unauthentic in any way. Every language embraces variation, and so all of the profiles we document here represent valid pronunciations of Tahltan words.

Finally, this article raises some issues for further research. It is generally assumed that the mergers and shifts discussed in this article applied to the entire series and not in piecemeal fashion. We have discussed one case where this did not seem to be the case, where voiceless aspirated stops resisted shifting (profile I/II), which we assume is a frequency effect and perhaps a frozen partial change. The other glaring example involves the avoidance of velar fricatives to shift to palatals, as illustrated in both profiles I and III. Future work may look to internal or external evidence to explain this dis-unity in an otherwise uniform set of consonant shifts.

\section{Appendix}

The four tables below consolidate the information about the forms in the affricates questionnaire, essentially expanding on each of the four columns from the charts in section 3. For each word, we give the historically reconstructed Proto-Athabaskan form (based on commonly cited references, including Leer (1979), Leer (1987), and Krauss (1979/2005)), the phonetic forms illustrating the observed variation (the first phonetic form is the standard), and finally the orthographic form of the standard form; see Carter (1994), Leer (1985), and Alderete and Blenkiron (2014) for details of the Tahltan spelling system. Conventions: $\mathrm{V}^{\mathrm{T}}=$ vowel constriction .

(A) Proto-Athabaskan alveolar series *ts

\begin{tabular}{|c|c|c|c|}
\hline & Reconstructed form & Phonetic forms & Orthographic form \\
\hline \multirow[t]{4}{*}{ a. vls asp } & *tse: 'stone' & t $\theta \mathrm{e}:$, tse: & ts $\underline{\overline{\mathrm{e}}}$ \\
\hline & *-tsỉ? 'head' & -t $\theta \mathrm{i}$, - $-\mathrm{tsi}$ ? & tssí \\
\hline & *tsə̉n' 'meat' & t $\theta$ en', tsen' & tsen' \\
\hline & *la+tsoy 'yellow' & $\operatorname{det} \theta$ oI, detsoI, & detsoy \\
\hline \multirow[t]{4}{*}{ b. vls eject } & *ts'a’k' 'dish' & t $\theta$ 'a?, ts'a? & ts'a' \\
\hline & *ts'è: $\chi$ 'thread' & t $\theta$ 'è:, ts'èh & ts $\underline{\prime}^{\prime} \overline{\mathrm{e}}$ \\
\hline & *ts'ən 'bone' & t $\theta$ 'enh, ts'enh & ts'enh \\
\hline & *ts'a:tl' 'diaper' & t $\theta$ 'a:tl, ts'a:tl & tś'ātl \\
\hline c. unasp & *dzə1 'mountain' & $\begin{array}{l}\text { dðel, eya dzełe 'high } \\
\text { mountain' }\end{array}$ & dzeł \\
\hline \multirow[t]{3}{*}{ d. fricative } & *sỏt' 'liver' & -ðet, -zet & zet \\
\hline & *-sá:d 'mouth' & -ðà:t, -zat & zāt \\
\hline & *sa:xy 'sand' & $\theta \mathrm{a}:, \mathrm{sa}:$ & $\underline{s a ̄}$ \\
\hline
\end{tabular}


(B) Proto-Athabaskan palatal series *ť̌

\begin{tabular}{|c|c|c|c|}
\hline a. vls asp & *tša? 'beaver' & tsa?, tša? & tsa' \\
\hline & *-tšżyə 'grandfather' & -tsiye, tšiye & tsiye \\
\hline & *tšixy '(red) ochre' & tsi:ts, tsi:dzi, tsih & tsīts \\
\hline \multirow[t]{4}{*}{ b. vls eject } & 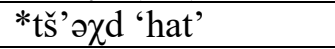 & ts'ah & ts'ah \\
\hline & *tš'ədə? 'blanket' & ts'ede, tš'ede & ts'ede \\
\hline & *tš'əwə 'spruce' & ts'u:, tš'u: & ts' $\bar{u}$ \\
\hline & *-tš'i:k' 'guts' & -ts'i’e, -tš'i?e & ts'i'e \\
\hline \multirow[t]{2}{*}{ c. unasp } & *džè: $\chi$ 'pitch' & dzehłen, džè:tl'en, dzehe & dzehłen \\
\hline & *-džəyə? 'inner ear' & -dzeke, -džešbıtle 'ear' & dzeke \\
\hline d. fricative & *ši: 'I/me' & SIni, sini & sini \\
\hline
\end{tabular}

(C) Proto-Athabaskan retroflex-palatal series $* t \check{s}^{r}$

\begin{tabular}{|c|c|c|c|}
\hline a. vls asp & *tšr 'a:n' 'excrement' & tsà:?, tšà:? & tsā' \\
\hline & *tšs $\partial$ ts̆ $^{\mathrm{r}}$ 'firewood' & tsets, tšetš & tsets \\
\hline & $* \varnothing+\mathrm{t} \breve{s}^{\mathrm{r}} \partial \chi \chi^{\prime c} \mathrm{cry}$ & -tsex, -tšai & tsex \\
\hline \multirow[t]{2}{*}{ b. vls eject } &  & nats'ih & nats'ih \\
\hline & *-tšs' ${ }^{\mathrm{r}}$ 'tšs' 'kidney' & -ts'əse, -ts'ese & ts'ese \\
\hline \multirow[t]{3}{*}{ c. unasp } & *džre:n 'day' & dzene $\theta$ & dzenes \\
\hline & *-džr e:yə? 'heart' & -dze:?, -dže:, -tse? & dze'’ \\
\hline & *-džra:də? 'shin' & -dza:ke, -dzodze, -dzada & dzāke \\
\hline \multirow[t]{2}{*}{ d. fricative } & $* \check{s}^{\mathrm{r}} \mathrm{a}:$ 'sun' & sa: & sā \\
\hline & *šr'é: $\chi$ 'saliva' & sek & sek \\
\hline
\end{tabular}

(D) Proto-Athabaskan velars $* k$

\begin{tabular}{|c|c|c|c|}
\hline \multirow{4}{*}{ a. vls asp } & *la+kən 'wrist' & -latšine, -latšine & lachine \\
\hline & *ke+kən 'ankle' & -ketšıne, -ketšine & kechine \\
\hline & *ka:n 'rain' & tša: & chā \\
\hline & *la+kuts' 'thumb' & -laštšo: & lashchō \\
\hline \multirow[t]{2}{*}{ b. vls eject } & *k'əx 'porcupine quills' & tš'ohe & ch'ohe \\
\hline & *k'ủ:ts' 'veins, gristle' & tšide, tšide & chide \\
\hline \multirow[t]{3}{*}{ c. unasp } & $*^{n}+1 \partial+\mathrm{gu}^{\mathrm{T}}: \mathrm{d}$ 'be afraid' & nedžıt & nejit \\
\hline & *gỉzə 'Canadian Jay' & tšošk'a?e, & choshk'a'e \\
\hline & *ga 'here' & dža:ni, dža:n & jāni \\
\hline \multirow[t]{5}{*}{ d. fricative } & *xən ‘(shaman's) song' & XIn & khin \\
\hline & *x...ts' 'brown bear' & xoh & khoh \\
\hline & *xว̉ts' 'hill, knoll' & $\mathrm{xI} \theta$, xIS & khis \\
\hline & $*_{\mathrm{x} \alpha}{ }^{\prime} \mathrm{t}$ ' 'scar' & $\mathrm{X} \Lambda \mathrm{S}$ & khas \\
\hline & *xəš 'black bear' & $\mathrm{S} \Lambda \mathrm{S}$ & sas \\
\hline
\end{tabular}

N.b.: * $\mathrm{x} \alpha$ 't' 'scar' has constriction.

\section{References}

Alderete, John \& Amber Blenkiron. 2014. Tahltan grammar synopsis. Manuscript, Simon Fraser University.

Blevins, Juilette. 2004. Evolutionary Phonology: The emergence of sound patterns. Cambridge: Cambridge University Press. 
Bob, Tanya. 1999. Laryngeal phenomena in Tahltan. Vancouver: University of British Columbia M.A. thesis.

Carter, Colin \& Tahltan Tribal Council. 1994. Tahltan children's illustrated dictionary. Dease Lake: Tahltan Tribal Council.

Greenberg, Joseph H. 1966/2005. Language universals: With special reference to feature hierarchies. Berlin: De Gruyter Mouton.

Hardwick, Margaret. 1984. Tahltan morphology and phonology. Toronto: University of Toronto M.A. thesis.

Hargus, Sharon. 1985. The lexical phonology of Sekani. Los Angeles: UCLA Doctoral dissertation.

Hargus, Sharon. 2007. Witsuwit'en grammar: Phonetics, grammar, morphology. Vancouver: UBC Press.

Hoijer, Harry. 1963. The Athapaskan languages. Studies in the Athapaskan languages, University of California Publications, Vol. 29, ed. by Harry Hoijer, 1-29. Berkeley and Los Angeles: University of California Press.

Huld, Martin E. 1983. Athapaskan bears. International Journal of American Linguistics 49.18695.

Krauss, Michael. 1964. Proto-Athapaskan-Eyak and the problem of Na-Dene: The phonology. International Journal of American Linguistics 30.118-31.

Krauss, Michael. 1973. Na-Dene. Current trends in linguistics, Vol. 10. Linguistics in North America, ed. by Thomas A. Sebeok, 903-78. The Hague: Mouton.

Krauss, Michael. 1979/2005. Athabaskan tone. Athabaskan prosody, ed. by Sharon Hargus \& Keren Rice, 55-136. Amsterdam: John Benjamins.

Krauss, Michael \& Victor Golla. 1981. Northern Athapaskan languages. Handbook of North American Indians. Volume 6. Subartic, ed. by June Helm, 67-85. Washington: Smithsonian Institute.

Krauss, Michael \& Jeff Leer. 1981. Athapaskan, Eyak, and Tlingit sonorants. Alaska Native Language Centre Research Papers, Number 5.

Leer, Jeff. 1979. Proto-Athabaskan verb stem variation, part one: Phonology. Fairbanks, Alaska: Alaska Native Language Center, University of Alaska.

Leer, Jeff. 1985. Report on the recommended Tahltan orthography. From the Tahltan Orthography Workshop held at Yukon Native Language Center, Whitehorse, Yukon, July, 1985. Manuscript, Alaska Native Language Center, University of Alaska.

Leer, Jeff. 1987. Navajo and Comparative Athapaskan. The Navajo language: A grammar and colloquial dictionary, ed. by Robert Young \& William Morgan, 264-301. Albuquerque: University of New Mexico Press.

Leer, Jeff. 1996. The historical evolution of the stem syllable in Gwich'in (Kutchin/Loucheux) Athabaskan. Athabaskan language studies, ed. by Eloise Jelinek, Sally Midgette, Keren Rice \& Leslie Saxon, 193-234. Albuquerque: University of New Mexico Press.

McIlwraith, Thomas. 2012. We are still Didene: Stories of hunting and history from Northern British Columbia. Toronto: University of Toronto Press.

Moore, Patrick J. 2002. Point of view in Kaska historical narratives [Part 2: Kaska grammar]: Indiana University.

Nater, Hank. 1989. Some comments on the phonology of Tahltan. International Journal of American Linguistics 55.25-42. 
Nater, Hank. 2006. Athabascan verb stem structure: Tahltan. What's in a verb? Studies in the verbal morphology of the languages of the Americas, ed. by Grazyna Rowicka \& Eithne B Carlin, 53-72. Utrecht: LOT.

Pierrehumbert, Janet. 2003. Probabilistic phonology: Discrimation and robustness. Probability theory in linguistics, ed. by Rens Bod, Jennifer Hay \& Stefanie Jannedy, 177-228. Cambridge, MA: The MIT Press.

Randoja, Tiina Kathryn. 1989. The phonology and morphology of Halfway River Beaver. Ottawa: University of Ottawa, Doctoral dissertation.

Rice, Keren. 1994. Northern Athapaskan languages - An introduction. Manuscript, University of Toronto.

Rice, Keren. 2004. Language contact, phonemic inventories, and the Athapaskan language family. Linguistic Typology 8.321-83.

Shaw, Patricia. 1991. Consonant harmony systems: The special status of coronal harmony. The special status of coronals, ed. by C. Paradis \& J. F. Prunet, 125-57. New York: Academic Press.

Sheppard, Janice R. 1983. The history and values of a Northern Athapaskan Indian village: University of Wisconsin, Doctoral dissertation.

Story, Gillian. 1975. Tahltan: An Interpretation of Ken Hale's Data at Telegraph Creek. Unpublished handwritten manuscript. 